\title{
Imágenes de infancia en el cine sobre el conflicto armado interno colombiano
}

Childhood images in cinema about the armed conflicto colombian internal

\author{
Ángela Inés Palacio Baena* \\ (iD) https://orcid.org/0000-0001-7560-3701
}

Natalia Jiménez Giraldo**

(iD) https://orcid.org/0000-0003-3591-0779

Tipo de Artículo: Informes de Investigación y ensayos inéditos

Doi: 10.17533/udea.unipluri.20.2.013

Palacio, A., \& Jiménez, N. (2020). Imágenes de infancia en el cine sobre el conflicto armado interno colombiano. Uni-Pluriversidad, 20(2). e20202013. doi: 10.17533/udea.unipluri.20.2.013

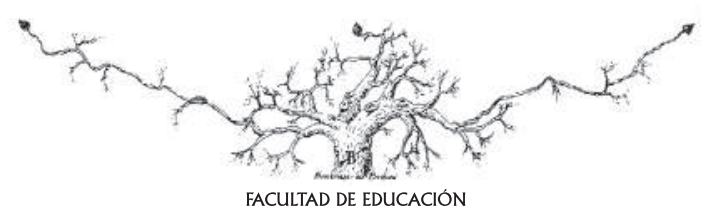

Recibido: 2020-03-25 • Aprobado: 2020-12-17

* Magíster en Educación, profesora de cátedra de la Licenciatura en Educación Infantil de la Facultad de Educación de la Universidad de Antioquia, integrante del semillero de investigación Conversaciones entre Pedagogía y Psicoanálisis.

Email: angela.palacio@udea.edu.co

** Licenciada en Pedagogía infantil de la Facultad de Educación de la Universidad de Antioquia.

Email: natalia.jimenezg@udea.edu.co 


\title{
Resumen
}

Este artículo presenta los resultados de la investigación Imágenes de infancia en el cine sobre el conflicto armado interno colombiano que concluyó en 2019. Interroga imágenes unívocas de infancia y conmina a escuchar en los materiales seleccionados las voces de los personajes, niños y niñas, y lo que el cine nos enseña acerca de su lugar en el conflicto. A partir del concepto de imagen como representación, se analizan 7 filmes a través de las técnicas de análisis de los recursos expresivos y narrativos propuestas por Marzal y Gómez (2007). Los resultados evidencian, por un lado, que los niños y las niñas se presentan como víctimas: personajes sin nombre, silenciados, sin voz, sin saberes, desechados; y por otro, que son sujetos que toman decisiones, se resisten, tienen conocimiento del conflicto y proyectan su vida de otras maneras. De acuerdo con estas categorías se esbozan dos líneas de trabajo para futuras investigaciones: la exploración de la condición de los niños y las niñas como victimarios y una revisión documental que ponga la mirada tanto sobre el reclutamiento forzoso de los niños y las niñas como sobre su vinculación "voluntaria" al conflicto armado.

Palabras clave: cine, conflicto armado colombiano, imágenes de infancia.

\begin{abstract}
This article presents the results of the research Images of Childhood at the Cinema on the Colombian Internal Armed Conflict, concluded in 2019. This research questions univocal images of childhood and demands to listen in the selected materials to the voices of the characters, boys and girls, and what the movies teach us about their place in the conflict. From the concept of image as representation, seven films are review based on the analysis techniques of expressive and narrative resources proposed by Marzal and Gómez (2007). On the one hand, the results show that boys and girls are presented as victims: unnamed, silenced, voiceless, unknowing, and discarded characters. On the other hand, the results also show that they are subjects who make decisions, resist, have knowledge of the conflict and project their life in other ways. According to these categories, two lines for future research emerge: inquiry into the condition of boys and girls as perpetrators; and documentary review focused on forced recruitment of boys and girls, and on their "voluntary" incorporation to the armed conflict.
\end{abstract}

Keywords: cinema, Colombian armed conflict, childhood images. 


\section{INTRODUCCIÓN}

Los niños y niñas de Colombia han sido vinculados históricamente a las guerras (Rodríguez y Mannarelli, 2002) y al conflicto armado interno (Centro Nacional de Memoria Histórica - $\mathrm{CNMH}-$, 2018; 2017; 2016; 2013). Esos trabajos refieren que han sido mensajeros, combatientes, soldados; han sufrido reclutamiento, desaparición de ellos o sus seres queridos, asesinatos, desplazamiento y han habitado contextos en los que han padecido los efectos de las violencias en sus diversas manifestaciones. Las publicaciones académicas y en medios de comunicación muestran cifras alarmantes acerca de la situación de los niños y las niñas como víctimas y como integrantes de grupos al margen de la ley; datos y análisis que indican las dimensiones de un problema que la pedagogía también debe pensar.

El cine da cuenta de la vinculación de los niños y las niñas al conflicto armado colombiano que, aunque parta de una idea ficcional o real, permite un encaramiento con el rostro de la infancia: "el cine nos pone cara a cara con el comportamiento de la infancia, con su movimiento, con su corporeidad, con su gestualidad propia" (Larrosa, 2006, p.116). El cine también ofrece la posibilidad de educar la mirada para ver otras infancias y tomar distancia de estereotipos que finalmente "no representan a los niños sino a nosotros mismos" (Larrosa, 2007, p. 20). Afirmar que el cine permite "educar la mirada" (Dussel, 2006) significa poner en debate posiciones éticas, pensar otras formas de transmisión, de producción de los saberes, encontrar palabras que enriquezcan las imágenes e imágenes que abran la multiplicidad de formas de decir o expresar aquello que se nos presenta como innombrable, en este caso lo que ocurre y deja una guerra como la que ha vivido Colombia desde la segunda mitad del siglo XX.

El cine como "espectáculo de masas... vehículo de formación, de opinión, más aún, de imaginarios culturales, con poder de seducción y movilización socio individual" (Zapata, 1998, p.51), constituye un referente para la comprensión y construcción de memoria histórica y específicamente de los sucesos adversos y terribles del conflicto armado. El cine resulta ser un medio idóneo para construir memoria, para analizar nuestra historia y para evitar su repetición.

El llamado séptimo arte se ofrece también como una herramienta que brinda rostro a las cifras. De acuerdo con Larrosa (2006), "el rostro enigmático de la infancia no se refiere solo a que el cine mire y nos enseñe a mirar gestos y rostros de los niños, sino que el cine se enfrenta y nos enfrenta a una mirada infantil" (p. 118), a unos silencios y a unas representaciones.

En la investigación a partir de la cual se deriva el presente texto, la imagen se entendió como un concepto, una idea, un recuerdo, una imaginación-interpretación de la realidad, una representación y ésta como construcciones mentales, declaraciones y opiniones que permiten elaborar un "marco de referencias que facilita nuestras interpretaciones de la realidad y guían nuestras relaciones con el mundo, por lo que llegan a estar profundamente embebidas en nuestro tejido cultural" (Vergara, 2008, p. 58); por 
lo tanto son "al mismos tiempo, sociales e individuales, objetivas y subjetivas. Son sociales y objetivas porque se construyen históricamente como resultado de una multiplicidad de operaciones de clasificación de la sociedad (Diker, 2008, p. 45).

Las imágenes son "dispositivos privilegiados para el estudio de una mirada de época, o de múltiples miradas, construidas social e históricamente y forman parte de la compleja trama cultural" (Szir, 2006, p. 128). Así, cada época produce sus propias representaciones acerca de la infancia. Por ello, García (2000) señala que "la literatura, la pintura, el arte en general, nos han presentado al niño bajo muy distintas perspectivas, pero en todo caso... reflejan... lo que se pensaba sobre él en cada época concreta" (p.8). Los trabajos históricos sobre infancia dan cuenta de cómo los niños pasaron de no ser representados a ser concebidos como estorbos, adultos pequeños, irracionales, inocentes $\mathrm{y}$, más recientemente, como sujetos con derechos y seres racionales capaces de tomar decisiones.

La perspectiva de Arfuch (2017) acerca de la imagen señala que:
La imagen siempre convoca la palabra y esto es esencial en la elaboración de memorias traumáticas, pero también en todo proceso de educación y formación. Articular imagen y palabra, darle sustento a la visualidad - en el relato, la poesía, el análisis, la interpretación- no supone atenuar la potencia del ver, como sentido privilegiado en la cultura contemporánea, sino revalorizar también la importancia de escuchar ${ }^{1}$... Pero sin olvidar que tanto palabra como imagen siempre en desajuste, como exceso o como falta, [son] incapaces de alcanzar la dimensión "exacta" del acontecimiento. (p. 6)

Lo que Arfuch sugiere es que no se trata de una correspondencia exacta entre la imagen y lo que de ella podemos decir, sino de una aproximación y unas maneras de leer lo que vemos como espectadoras e investigadoras. Aunque se diga que una imagen vale más que mil palabras, la autora invita a ver, a escuchar y a articular imagen y palabra para crear sentidos. Hacer una lectura a filmes para presentar imágenes de infancia en el cine sobre el conflicto armado colombiano es interesante, al menos por dos razones: permite visibilizar imágenes de infancia en el material fílmico interpretado y explorar la potencia que tiene el cine como espejo para ponerle rostro a una realidad como la de los niños y las niñas en el conflicto.

\section{RUTA METOdológicA}

Para la investigación en cuestión, de corte cualitativo y enfoque hermenéutico, se rastrearon un total de 39 producciones fílmicas, realizadas entre 1981 y 2015, acerca de la violencia bipartidista y el conflicto armado interno que incluían largometrajes, documentales y cortometrajes. La mayoría de estos filmes se basaron en hechos reales ocurridos en distintos lugares del territorio colombiano y en diversos momentos de la historia reciente.

Para la selección de los materiales fílmicos definimos los siguientes criterios: a) que incluyeran el conflicto armado como contexto, b) que contaran con la presencia de personajes niños y niñas o de adultos que 
narraran infancias; c) que hubiesen sido producidos entre 2010 y 2015. Del total rastreado, 25 filmes cumplían el primer criterio, pero solo siete todos los demás. De manera que elegimos cuatro películas: Alias María (2015), Los colores de la montaña (2010), Retratos en un mar de mentiras (2010) y Todos tus muertos (2011), y tres documentales: No hubo tiempo para la tristeza (2013), Impunity (2010) y Pequeñas voces (2010) para la realización del estudio.

Para la descripción e interpretación de los materiales fílmicos seleccionados retomamos algunos aspectos de cuatro fases que proponen Marzal y Gómez (2007, pp. 48-51) en su texto sobre interpretación de un filme. Estas fueron: 1) "Estudio del nivel contextual", en este caso, el conflicto armado. Hicimos revisión documental, exploramos información sobre fichas técnicas y bibliografía sobre estudios críticos de la obra fílmica e identificamos si se fundamentaba en hechos históricos o en ficción. 2) "Estu- dio de la materialidad del filme". Segmentamos diálogos de los personajes niños o que hicieran referencia a la infancia y pusimos el foco en detalles puntuales que nos permitieran construir imágenes de infancia. 3) "Análisis de los recursos expresivos y narrativos", como la fotografía, la duración, los ángulos, la iluminación. Dimos sentido a las frases, imágenes, fotografías, miradas, gestos, objetos, silencios de los niños y las niñas o de narrativas de adultos referidas a la niñez. 4) "Interpretación global del texto fílmico". Identificamos cuándo hablan los niños y las niñas o cuándo son hablados por otras personas; pensamos cómo nombrar como espectadoras las imágenes de infancia inferidas de las producciones cinematográficas seleccionadas y leídas a la luz de algunos autores. Esta "fase interpretativa es fundamentalmente subjetiva" (Marzal y Gómez, p. 52) dado que hay multiplicidad de posibilidades, perspectivas e intereses en el trabajo hermenéutico que cada investigador puede poner a trabajar.

\section{IMÁGENES DE INFANCIA}

Para un espectador investigador, analizar una película o documental cinematográfico implica considerar el filme como una obra de arte, susceptible de engendrar un texto...que sujeta sus "significaciones sobre estructuras narrativas, sobre aspectos sonoros y visuales y produce un efecto sobre el espectador, se trata de una obra que pertenece a un contexto histórico en sus formas, estilo y evolución" (Aumont y Marie, 1988, p. 8, como se citó en Marzal y Gómez, 2007, p. 4).

Las imágenes fílmicas, pictóricas, en tanto dispositivos articulados a la palabra, permiten acercarse y bordear un acontecimiento; pero también, es posible, como espectadoras e investigadoras, construir imágenes y representaciones de infancia en el cine sobre el conflicto armado colombiano a partir de un trabajo de interpretación que pretende mostrar diversas maneras de nombrar la infancia vinculada al conflicto. Entendemos la infancia como una categoría social, cultural y discursiva que se constituye en cada época y geografía específicas, determinada por condiciones económicas, políticas e ideológicas concretas; de ahí que no se trate de una concepción unívoca, eterna, 
universal, invariable o natural. En ese sentido, se trata de multiplicidad de imágenes, concepciones, representaciones que han variado a lo largo de los siglos (Alzate, 2002).

Acercarse al universo representacional o a las imágenes construidas acerca de la infancia en prácticas, discursos, arte y cotidianidad es importante para la formación de maestras/os, toda vez que se trata de aquello que circula sobre lo que se considera que es la infancia en diversos momentos históricos: "cada sociedad, cada cultura define explícita o implícitamente qué es infancia, cuáles son sus características" (Alzate, 2003, p. $16)$; en consecuencia, qué atributos le confiere, qué tipos de relaciones entre adultos y niños establece, qué prácticas educativas y de cuidado instala. El arte, el cine en este caso concreto, muestra representaciones que dicen de la infancia, de una época y de un fenómeno como lo es la vinculación de los niños y las niñas al conflicto armado colombiano.

Las concepciones de infancia han variado dependiendo de las condiciones socioculturales e históricas en las que los niños y niñas han vivido; de las relaciones parento-filiales y de las formas de socialización (Alzate, 2003). Según Ariès (1986), en la antigüedad no se representaba a los niños, luego fueron tratados como adultos en miniatura; la modernidad los concibe como carentes de razón, inocentes, débiles, incapaces y; en la actualidad, nos referimos a los niños y las niñas como sujetos de derechos y deberes, con capacidad de tomar decisiones y de resistirse a los mandatos del adulto. Esto no significa que en el presente no pervivan representaciones ancladas en otras épocas y momentos de la historia. Además, las representaciones que construimos sobre infancia no sólo dan cuenta de una época, sino que cada época construye sus propias representaciones acerca de infancia.

Presentamos dos imágenes de infancia derivadas de la interpretación del material fílmico analizado: en primer lugar, una mirada sobre niños y niñas víctimas que carecen de nombre, de voz, de saberes, silenciados y desechados. En segundo lugar, imágenes en las que los niños y las niñas se resisten, toman decisiones, proyectan su vida de otra manera, lo cual nombramos como "infancia política". No es pretensión clasificarlos en esas imágenes, pues entendemos que un sujeto puede moverse en distintas posiciones, según las circunstancias y situaciones en las que se encuentre. En palabras de Zemelman (2010): "Al abordar a la subjetividad como dinámica constituyente, el sujeto es siempre un campo problemático antes que un objeto claramente definido, pues desafía analizarlo en función de las potencialidades y modalidades de su desenvolvimiento temporal" ( $p$. 357).

\section{LOS NIÑOS Y LAS NIÑAS VÍCTIMAS}

En relación con los efectos de la guerra en Colombia, la revista Semana (2014) señala que de acuerdo con el CNMH, los sesenta años de conflicto armado han dejado más de dos millones de niños y niñas "víc- timas de masacres, secuestros, asesinatos, desplazamiento y desapariciones forzadas" $\mathrm{y}$ que han "obligado a varias generaciones a crecer a pesar del dolor de sus recuerdos" (párr. 1). 
Este mismo medio, en una entrevista a tres expertos, para conocer sus opiniones acerca de los niños y las niñas víctimas, pregunta: ¿Cómo puede salir adelante un país que ha tratado así a sus niños? ¿Qué adultos se están formando en medio de la barbarie? José Luis Campo, director de la organización Benposta, quien ha trabajado durante mucho tiempo con niños víctimas, responde que "el desafío es romper con esos estigmas para tratarlos como personas y no con la etiqueta de niño excombatiente, desplazado, víctima de mina antipersona" y agrega: "Yo pienso que lo primero que hay que garantizarles a los niños es un presente digno" (Semana, 2014, párr. 15).

Un elemento común para nombrar los daños, perjuicios o efectos negativos del conflicto armado en Colombia es el de víctima, tema que en la legislación colombiana $\mathrm{y}$ en la literatura son relativamente recientes. El Derecho Internacional Humanitario -DIH y la Convención sobre los derechos del niño², en su Artículo 39 enuncia que "los Estados Partes adoptarán medidas para la recuperación física y psicológica de todo niño víctima... de conflicto armado". La Ley 418 de 1997 consagra el Título II a la "Atención a las víctimas de hechos que se susciten en el marco del conflicto armado interno". Así mismo la Ley 387 de 1997, en el Artículo 19, Numeral 7, delega en el ICBF (Instituto Colombiano de Bienestar Familiar) la atención a los niños y las niñas en zonas de desplazados. El Artículo 6 de la Ley 782 de 2002 define lo que se considera una víctima de la violencia política e incluye expresamente a los "menores que hayan tomado parte en las hostilidades o hayan sido víctimas de la violencia política, en el marco del conflicto armado interno". Esta doble condición, en el caso de los niños y las niñas, exige al Es- tado en razón de su vulnerabilidad asistencia y atención.

Con los trabajos de Lamus (2001), las víctimas empiezan a cobrar visibilidad y en el año 2011, la Ley 1448 o Ley de Víctimas y Restitución de Tierras les da un lugar. Esta Ley, en su Artículo 190, ratifica el reconocimiento de los niños, niñas y adolescentes como víctimas y habla de la restitución de derechos, de la protección igualitaria y sin discriminación de las personas menores de 18 años.

En varios de los materiales fílmicos que se analizaron, los niños y las niñas son víctimas, son despojados de sus nombres o nombrados como "alias". Esto fue lo que leímos en Todos tus muertos, Pequeñas voces, Alias María, No hubo tiempo para la tristeza e Impunity. En la primera cinta, se refieren a él como "niño" o "hijo"; en la segunda sólo se conoció el nombre de Jazmín, pese a que hablaron más de cinco niños; durante todo el documental se escucharon sus testimonios, pero sus nombres no. Atribuimos esta ausencia, para el caso de los documentales, a una decisión de los investigadores y productores relacionada con una consideración ética para proteger su identidad, al ser testimonios reales; en la tercera, María es "alias" $\mathrm{y}$, en la cuarta y quinta cintas, los niños y las niñas solo aparecen como datos o como relatos, pero no aparecen sus nombres o son cambiados por "alias".

Cuando los niños y las niñas son nombrados como "alias" en los grupos armados ilegales son despojados de sus nombres, su pasado, su historia. El nombre da una identidad, pero la identidad no se constituye de una vez y para siempre, no es inmutable, no es algo dado, ni hace referencia a un atributo 
del sujeto; tampoco es homogénea ni depende de un rasgo en particular del sujeto (Frigerio y Diker, 2008, p. 42). "Gardiner dice que en el forjamiento de un nombre propio no solo está el carácter de identificación sino también el carácter distintivo" (citado por Zelis, 2012, p. 778); así, el nombre permite diferenciarnos del otro, en medio de un común, de un colectivo o comunidad.

De esta manera, el modo en que nos nombran, nos nombramos, miramos y nos miran, "tienen efectos «reales») sobre las formas de percibirse y de actuar" (Frigerio y Diker, 2008, p. 38). Y esto ocurre porque las representaciones determinan prácticas concretas y modos de nombrar. "Dicho de otro modo, los nombres, las palabras, las etiquetas producen efectos... la imposición de un nombre... es un acto de institución de identidad... la construcción de una identidad no es resultado de cualquier acto de nombramiento" (p. 39). Por eso, cuando a los niños y a las niñas no se les nombra o se les pone un "alias" se les está borrando de sus linajes, de sus historias, de sus filiaciones.

Otra imagen relacionada con su condición de víctima es la de los niños y las niñas silenciados y sin voz. Observamos que en los documentales Impunity y No hubo tiempo para la tristeza no hablan; son cuerpos infantiles que se presentan como una imagen en la pantalla, una fotografía, que dice a otros. Al parecer, en esas cintas siguen teniendo esa mudez de la que la palabra infancia proviene. Pavez (2012) señala que para Wasserman (2001, p. 61) el origen etimológico de la palabra infancia procede del latín in-fandus, que expresa más bien "que no es legítimo para tener la palabra... se refiere... a quienes no tienen permitido hablar, y no tanto a quienes carecen de este atributo por los años de edad" (p. 82). Por ello, las nuevas perspectivas de la infancia ponen el debate acerca de una representación negativa de la misma: "aunque hablen, no tienen nada interesante que decir, no vale la pena escucharles" (Casas, 2006, p. 30), con ello se pone en duda y se desprecia su capacidad para opinar y hablar acerca de los que les compete y afecta.

En el marco del conflicto, no solo los niños y las niñas carecen de voz; eso mismo también les pasa a otros. En su análisis de los Colores de la Montaña, Arias (2013) refiere que en la película la población ha sido silenciada (p. 601) y que se ha convertido en "parte sin parte", debe desplazarse y obedecer mandatos de otros. No tiene voz, al igual que la infancia, cuya palabra no tiene legitimidad. Esta mudez se nos presenta en las víctimas del conflicto como lo que se juega para proteger la vida y librarse en ocasiones del despojo y el desplazamiento. En Pequeñas voces, cuando llegan los guerrilleros amenazan a la familia de un niño campesino advirtiendo que, si no se van, se lo llevan. Ellos (su abuela y su tío) se quedan en silencio, no pueden decir nada, es la vida de ellos y la del niño la que está en juego.

Otro aspecto leído en Los colores de la Montaña es que la población adulta disfraza situaciones familiares y eventos referidos al conflicto en un intento por proteger a los niños y las niñas, ocultan información a la que ya han accedido. Un ejemplo es que Julián está enterado de lo que pasa con su hermano: "en la casa dicen que se fue a trabajar a la costa donde un tío, pero yo ese cuento no me lo creo, para mí que él se fue pa'l monte" le dice Julián a Manuel, quien agrega "pa' la guerrilla" (Arbeláez, 2010). Algo parecido observamos en Todos tus muertos, cuando 
Salvador y Carmen dejan en casa a su hijo; nunca se observa un diálogo con él sobre la pila de muertos que aparece en su finca, ni sobre la presencia del alcalde y los policías, solo pregunta si lo van a matar. En Retratos en un mar de mentiras tampoco aparece una mediación o aclaración para Marina sobre esos uniformados que aparecen en la cotidianidad de su pueblo, a quienes ella mira en un gesto de desconfianza porque vio asesinar a su familia a manos de los paramilitares y debió desplazarse con su abuelo a Bogotá (Gaviria, 2010).

En las cintas analizadas callar se vuelve un mandato, una manera de protegerse y proteger a la familia. En Impunity, las Autodefensas Unidas de Colombia (AUC -grupo paramilitar-) hablan y la población solo escucha, es atemorizada. En Retratos de un mar de mentiras hablar es un riesgo que se puede pagar caro como en el caso del primo de Marina que fue asesinado y en el de la maestra que dice "a los que nos quedamos nos tocó quedarnos con el pico cerrado (Gaviria, 2010). En Todos tus muertos es necesario garantizar que nadie pueda dar testimonio de una masacre: "aplican el criterio espeluznante de que «todo sobreviviente es un mal enemigo para toda la vida»" (Agudelo, 2017, p. 39), por eso, el alcalde ordena asesinar a los representantes de los derechos humanos y al periodista.

Silenciar y disfrazar situaciones en aras de proteger a los niños y las niñas podría interpretarse en dos sentidos: callar o aparentar no saber son maneras de protegerlos del sufrimiento, del peligro; pero a su vez, pone a los niños y niñas en cierta posición de inferioridad, cuando les ocultamos, disfrazamos aquello que les compete y afecta. Los personajes adultos también nos mues- tran imágenes de infancia: les suponen a los niños y a las niñas un no saber y creen que pueden engañarlos con la idea de evitarles preocupaciones o riesgos.

En otra escena del documental Impunity, la psicóloga atiende a una familia porque al niño le dicen que la mamá está en el cielo, le ocultan que la mataron. La posición de la psicóloga es que:

Debes... hablarle con claridad... en el lenguaje que entienden los niños, porque personas... que están en contra de la ley se llevaron a tu mamita, parece que tu mamita ya murió... y parece que está en el cielo (...) Le vas a explicar con verdades sin disfrazar la verdad y ahí está la sabiduría de nosotros. Es que Dios lo quiso así porque Dios quería un ser tan querido como tu mamita, tu mamá era una mujer muy buena (...) fíjate que a ella se la llevó el Señor porque la quería mucho. Inculcarles este tipo de situaciones y de valores a los niños para que ellos entiendan que la justicia divina es perfecta. Y que sí ocurrió era porque era el agrado de Dios tener esa alma allá en el cielo, entonces explicarle de esta manera a los pequeños. (Lozano y Morris, 2011)

Varios asuntos llaman la atención en las palabras de la psicóloga. Primero, la imagen de los adultos de una infancia inocente que no sabe o no puede saber acerca de lo que le interroga. Por eso los engañan y responden con mitos a lo que les preocupa. Segundo, que hay poca diferencia entre lo que llama "verdad" y lo que la familia ha respondido al niño cuando pregunta por su mamá; de alguna manera ella también disfraza la verdad y agrega explicaciones que podrían generar más confusión en el niño, porque es difícil comprender que Dios lo ama y quiere tener el alma de su mamá en el cielo y a él sin mamá. Lo mínimo que podría pensar el niño 
es que Dios es injusto porque él también quiere a su mamá y no tenía por qué llevársela; pero, además, que no puede confiar en los adultos que lo engañan y lo ponen en el lugar de no saber o no poder saber. Por otra parte, responsabilizar a Dios, a la justicia divina por las acciones de los paramilitares no deja de ser un engaño: usar la palabra "parece" cuando es evidente que la madre fue asesinada, es una respuesta que tampoco conviene al niño.

Para los investigadores, esos silencios o esas maneras de maquillar la realidad impidieron saber la verdad desde las víctimas, quienes guardaron su voz, la escondieron, se protegieron. A eso se suma que en regiones apartadas no había presencia del Estado, ni escucha ni acción por parte de la autoridad. Sin embargo, la investigadora Bello del $\mathrm{CNMH}$ dice que en No hubo tiempo para la tristeza tuvieron que "recurrir al discurso del victimario, para validar, para reconocer, el discurso de la víctima” (Betancur, 2013).

Otra imagen que se derivó del análisis del material fílmico, y que muestra cómo los niños y las niñas son víctimas, es la que nombramos como niño "deshecho". Este término se refiere a quien es sometido o se somete a ser el objeto del otro, quien lo pone a merced de su arbitrio y capricho; un otro que en general peca de exceso y del que el niño o niña no puede despegarse fácilmente, pues está atado, encadenado a sus decisiones. En el material analizado el niño "desecho" es aquel que no sirve, que ya no es útil, que se descarta o simplemente se arruma, que se elimina o es dejado como residuo o desperdicio en cualquier lugar. Es un estorbo en tanto no está al nivel de una corporalidad deseada y exigida para un escenario como el de la guerra; su vida está en manos de un otro que define su destino. Los niños y las niñas son como cosas que se descartan desde antes de nacer, o por habitar determinado espacio, pertenecer a determinada familia o pueblo o, después de haber sido utilizados por los grupos armados. En las producciones de Alias María, Pequeñas voces, Todos tus muertos, Impunity y No hubo tiempo para la tristeza inferimos esa imagen.

Así, por ejemplo, en Alias María hay niños que pueden nacer y otros que no por decisión de alguien que tiene un rango o mando en la organización armada. El hijo del comandante puede nacer, pero el de María no, aunque ella lo desee, hay que abortar si es hijo del guerrillero raso. María hace un lugar en su deseo para ese hijo que viene y lucha por él hasta que logra escapar. Yuldor, quien acompaña a María en una huida fallida fue fusilado porque ya no puede caminar, como consecuencia de las heridas que le produjeron durante una emboscada de los paramilitares al campamento donde permanecían por esos días. Este niño de 12 años representa una carga, es "inservible" para el grupo armado.

En Alias María, niños como Yuldor, María y Bayron son víctimas en el doble sentido atribuido por la Ley 782 de 2002, pero María no se somete y se fuga para salvar la vida de su hijo. El bebé - hijo del comandante y Diana- recién nacido muere quemado durante una emboscada paramilitar a la zona. En el documental No hubo tiempo para la tristeza, los testimonios hablan de 48 niños muertos en Bojayá, pero también de la persistencia de una comunidad que quiere cuidar a sus niños y niñas. En Todos tus muertos, por la mano de la muñeca que recogió el niño, cuando presencia la pila de muertos dejada en la finca de Salvador, su padre, su- 
ponemos que hay una niña que fue desechada junto con las demás personas asesinadas. En pequeñas voces un niño que fue reclutado comenta "que viva el que quiera" porque el que está herido lo matan, ya no sirve para batallar. Tanto en Impunity como en No hubo tiempo para la tristeza los cuerpos son arrojados en cualquier lugar como cualquier cosa. Así lo relata en Impunity (documental que presenta lo que fue el denominado Proceso de Justicia y Paz con los paramilitares -AUC- entre los años 2002 y 2008) la hermana del niño de doce años que fue degollado por los paramilitares en un potrero y que tuvo que ser recogido por ella y la madre, porque solo hasta el día siguiente apareció el ejército. Por otra parte, Hernán Giraldo, alias "el viejo" dice: "murieron muchos inocentes, es cierto, murieron niños" ... "у yo hubiera querido no tener que hacerlo, pero así es el destino" (Lozano y Morris, 2010), "destino" que desafortunadamente sufren los niños y las niñas en Colombia por una guerra inútil que no tiene ninguna consideración con la población civil. En No hubo tiempo para la tristeza, documental resultado del informe ¡Basta ya! Colombia. Memorias de guerra y dignidad (2016), elaborado por el CNMH se relata que en la masacre de Bojayá (2002) murieron muchos niños, no importó respetar su vida, ni su condición.

\section{LOS NIÑOS Y LAS NIÑAS ACTORES Y PORTADORES}

\section{DE PALABRA}

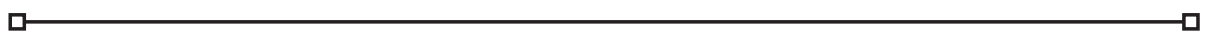

Otras Imágenes de infancia devinieron de la acción y de la palabra de los niños y las niñas en las producciones cinematográficas que se analizaron. En ellas identificamos que toman decisiones e incluso que se resisten, son capaces de asumir posiciones, son portadores de unos saberes. En esta dirección, Pavez (2012) señala que el principal aporte de los estudios sociológicos contemporáneos sobre la infancia es resaltar "la importancia de la experiencia social en la infancia como fuente para el surgimiento del agente social capaz y autónomo, alejado de la imagen del organismo respondiente" (pp. 90-91). Reconocer, de acuerdo con los nuevos estudios sociales sobre la infancia, que los niños y las niñas son sujetos políticos significa que son actores y agentes sociales, que pueden participar de "diversas maneras en la vida social, aunque de forma diferente a las personas adultas" (p. 81).
En ese sentido, los actos y palabras de los niños y las niñas en cintas como Pequeñas voces, Los colores de la montaña, Todos tus muertos, Alias María muestran un saber sobre el conflicto, las armas, los grupos armados, los territorios. María se resiste a abortar, oculta su embarazo al padre, se niega a asistir a la consulta con el médico contratado para practicar los abortos a las guerrilleras, reclama por qué su hijo no puede nacer como otros y se arriesga con una fuga.

Otro ejemplo es el documental Pequeñas voces, en el que cuatro niños hablan del conflicto: uno narra que decidió irse para la guerrilla, otro habla de que perdió un brazo y una pierna por el impacto de una bomba, otro más refiere que para evitar ser reclutado su familia se desplazó a Bogotá y una niña refiere que sufrió la desaparición forzada de su padre. En esta cinta los niños y las niñas son protagonistas: relatan su versión acerca 
del conflicto armado en Colombia; levantan su voz para "interpelar, para decir "no más". Ellos quieren soñar, jugar y retornar a los sitios de donde fueron desalojados. "Escucharlos es un paso obligado para que se abra paso a la reconciliación" (Agudelo, 2017, p. 58). Los niños se presentan en el documental con un saber, una historia y un conocimiento sobre el conflicto que podríamos nombrar como infancia crítica, pensante y analítica.

En pequeñas voces, los niños y niñas alzan su voz y resignifican sus vivencias para narrarlas a través de sus palabras y dibujos; encaran la realidad del conflicto y lanzan frases como "todas las fuerzas que tengan un arma siembran terror", reconociendo no solo la responsabilidad de los grupos armados al margen de la ley, sino también del Estado que desde la legalidad ha perpetrado crímenes de lesa humanidad como los falsos positivos, las masacres, $\mathrm{y}$ ha causado tanto terror como los grupos ilegales. Algunos relatan cómo llegaron a los grupos armados: a uno lo reclutaron por 50 mil pesos, otro refiere que el gusto por las armas lo llevó a vincularse a un grupo armado, una niña relata que a pesar de las promesas no se dejó reclutar: "nunca me deje convencer de ellos".

En el documental No hubo tiempo para la tristeza, los testimonios hablan de 48 niños muertos en Bojayá, pero también de la persistencia de una comunidad que quiere cuidar a sus niños y niñas. En Los Colores de la Montaña, Julián, Manuel y Poca Luz (Genaro), amigos de la escuela rural, están jugando futbol y su balón nuevo cae a un campo minado que afortunadamente solo produce la muerte de un cerdo. En compañía de la nueva maestra los niños y las niñas pintan un mural para borrar un grafiti que dice "guerrillero, ponte el camuflado o mue- re de civil" (Gaviria, 2010). Esta fue una manera de resistirse y de evitar que su escuela se convirtiera en centro de reuniones de los paramilitares.

Estos relatos nos enfrentan con una infancia que hemos nombrado política, en el sentido de que los niños y niñas son capaces de poner en palabras su propia experiencia y conocimiento del conflicto, de contarle al mundo sobre lo que les afecta y concierne, de proponer soluciones, de darle rumbo a su existencia, de analizar y tomar posición frente a la realidad de la que hicieron parte, los afectó y afectó a otros.

De esta manera, el cine nos permite reconocer unas infancias que padecen los efectos de las múltiples violencias, pero que al mismo tiempo son portadoras de un saber, de unas experiencias y esperanzas que contrastan con "el fatalismo determinista que concibe a los niños como autómatas condenados a reproducir el orden social en el que se desarrollan" (Ospina, Carmona y Alvarado, 2014, p.53). Estos autores agregan que los niños y las niñas "se constituyen en sujetos políticos en tanto su destino personal los liga a la discusión de la vida y destino comunes" (p.12). Se trata de niños y niñas que:

Por sí mismos y sin que existan condiciones, podrían crear nuevas realidades sociales y políticas. Los niños no son meras estructuras reproductoras, ni seres esencialmente pacíficos o violentos. Son sujetos activos, con capacidad de constituirse como sujetos políticos y de aportar a la construcción de paz en procesos de interacción con otros. (Ospina, Carmona y Alvarado, 2014, p.53)

Lo que además nos enfrenta con una visión de infancia que nos recuerda que la experiencia del conflicto es una marca que se porta en la memoria, en el cuerpo y en narra- 
ción; es una experiencia que trasciende y se resignifica porque un niño, una niña, puede ser hoy un guerrillero, un paramilitar, pero luego otra cosa: estudiante, trabajador... gestor de paz. De esto da cuenta, por ejemplo, el trabajo de González (2002 y 2019).

\section{CONSIDERACIONES FINALES}

El cine sobre conflicto armado interno colombiano deja ver "una estética del horror" (Agudelo 2017, p.46) e invita a asumir el deber de hacer memoria, de denunciar, de retratar, de hacer visible una tragedia de más de sesenta años para evitar su repetición y en la que el sufrimiento del otro nos compete e implica.

Por tanto, este artículo se propuso identificar imágenes de infancia en 7 filmes sobre conflicto armado. El cine con sus recursos estéticos, la imagen, los gestos, los colores, los paisajes, los sonidos, las narrativas, nos ofrece otras formas de transmisión que producen efectos en un espectador y que en el ámbito educativo se relaciona entre otras cosas, con el "deber de memorar". El trabajo con el cine se convierte en una manera de educar la mirada para interrogar estereotipos que hemos construido acerca de los niños y las niñas, ampliar perspectivas, reconocer otros discursos, otros lenguajes y proponer otros debates que complejizan nuestras miradas y reflexiones sobre la educación.

Un resultado importante que se derivó de este estudio es que coexisten imágenes de infancia como víctima y como actores y portadores de palabra. Esto se pudo evidenciar especialmente en la revisión documental y en las narrativas, silencios y miradas de los niños y las niñas en los filmes elegidos para este estudio.

Un ejemplo de este contraste son algunos de los testimonios que, durante los años
1998 y 1999, un grupo de siete niños y cuatro niñas desvinculados de grupos armados al margen de la ley y menores de 18 años ofrecieron a González (2002); quien 15 años después, ya adultos, logra obtener relatos de cinco de ellos. Dice una niña de sus hermanos guerrilleros: "los conquistaron, los convencieron y ellos, en esa pobreza, pues se fueron; también porque les gustaba" (p. 28). Ella misma ingresa a la guerrilla: "Yo estaba entre trece y catorce años. El guerrillero me dijo que allá era bueno, que a las mujeres les iba bien, que eran las niñas consentidas" ( $p$. $34)$. Otro niño relata que estuvo en la guerrilla desde los siete hasta los quince años: "las milicias me criaron y las FARC me terminaron de parar" (p. 52). Agrega: "una experiencia buena, me gustaba lo que hacía; la verdad es que no me arrepiento" (p. 51). Otro refiere que ingresó a un grupo paramilitar: "entramos en contacto y me quedaron como gustando. Miraba las armas, las cogía. En ese tiempo tenía doce años. Cuando cumplí los catorce años... les pedí que me llevaran... Insistí y a lo último aceptaron" (pp. 94-95). "Anduve con ellos dos años. Estaba muy amañado allá. No es por nada, pero me trataban bien, me daban lo que necesitaba. Yo tenía, gracias a Dios, todo" (p. 98). Otro niño que ingresó a los 13 años al ELN, relata: "un día mi papá me iba a pegar y yo le dije que si lo hacía me iba para la guerrilla y venía y lo pelaba, lo mataba" ( $p$. 122). "Llegué allá porque me gustaban sus ideales, estar con ellos, conocer otras cosas, pero no pensé que fuera tan cruel. Claro que 
a mí no me fue mal; les agradezco a ellos porque aprendí a cocinar: a lavar mis cosas, a saber que tenía que responder por mí mismo o si no, tenía que asumir las consecuencias" (p. 124).

En este sentido, el CNMH (2017) refiere que los niños en ocasiones muestran motivaciones relacionadas con la vida militar tales como el uniforme, las armas, el poder y la autoridad, además de la posibilidad de trabajo en un grupo armado.

Finalmente, del presente artículo se derivan dos temas para futuras investigaciones. Una que aborde la doble condición de los niños y las niñas como víctimas y como victimarios porque cometieron delitos cuando se vincularon o los vincularon a los grupos armados ilegales; esto nos sitúa en la discusión sobre la protección a la que tienen derecho de acuerdo con la Ley 782 de 2002 y la sanción a menores de 18 años de acuerdo con las leyes colombianas. Otra que, mediante una revisión documental, trabaje la hipótesis de que los niños y las niñas no se vinculan a los grupos armados ilegales solo de manera forzosa por reclutamiento y amenazas, también lo hacen por múltiples motivos y causas, algunos de los cuales apuntarían a una vinculación que en principio podría nombrarse como "voluntaria".

\section{Notas}

1. La negrilla en el original.

2. Colombia ratificó este tratado por medio de la Ley 12 de 1991.

\section{REFERENCIAS}

Agudelo, M. (2017). Cine y conflicto armado en Colombia. Medellín: UNAULA.

Alzate, M. (2002). Concepciones e imágenes de la infancia. Revista de Ciencias Humanas, Universidad Tecnológica de Pereira, 28(1), 13.

Alzate, M. (2003). La infancia: concepciones y perspectivas. Pereira-Risaralda: Papiro.

Arfuch (2017). Dilemas de la imagen: modos de ver y de ser. Recuperado de http://rayandolosconfines.com/reflex83_arfuch.html

Arbeláez, C.C. (director). (2010). Los colores de la montaña [película]. Tamayo, J. P. (productor).

Arias, H. J. (2013). Infancia y conflicto: sobre la tendencia a un cine 'no político' en Colombia. Palabra Clave [online], vol.16(2), pp.585-606. Recuperado de: http://www.scielo.org.co/scielo. php?pid=S012282852013000200014\&script $=$ sci_abstract\&tlng=es

Ariès, Ph. (1986). La infancia. Revista Educación 281. Historia de la infancia y de juventud, sep-dic.

Betancur, J. M. (director). (2013). No hubo tiempo para la tristeza [documental]. Centro Nacional de Memoria Histórica (productores). 
Carrillo, J. E., y Andradre, O. (directores). (2011). Pequeñas voces [documental] Salazar, C. y Toquica, C. (productoras).

Casas, F. (2006). Infancia y representaciones sociales. Recuperado de esearchgate.net/publication/27591450_Infancia_y_representaciones_sociale

Centro Nacional de Memoria Histórica y Sánchez, G. (dirección). (2013). No hubo tiempo para la tristeza [documental]. Investigación Centro Nacional de Memoria Histórica.

Centro Nacional de Memoria Histórica (2013a). ¡Basta ya! Colombia: memorias de Guerra y dignidad. Bogotá: Imprenta Nacional.

Centro Nacional de Memoria Histórica (2018). Cifras: los registros estadísticos del conflicto armado colombiano. Bogotá.

Centro Nacional de Memoria Histórica (2017). Una guerra sin edad. Informe nacional de reclutamiento y utilización de niños, niñas y adolescentes en el conflicto armado colombiano. Bogotá.

Centro Nacional de Memoria histórica y Bello, M. N., Suárez, A. F., \& Ramírez, M. M. (relatores). (2016). Hasta Encontrarlos. El drama de la desaparición forzada en Colombia. Bogotá, Colombia: Imprenta Nacional.

Centro Nacional de Memoria Histórica (2016a). Grupos Armados posdesmovilización (2006-2015). Trayectorias, rupturas y continuidades. Bogotá, Colombia: Imprenta Nacional.

Dussel, I. (2006). Educar la mirada Reflexiones sobre una experiencia de producción audiovisual y de formación docente. Dussel, I. y Gutiérrez, D. (comps.) (2006). En Educar la mirada. Políticas y pedagogía de la imagen, Buenos Aires, Argentina: Manantial - Flacso - OSDE, pp. 277-293.

Fondo de las Naciones Unidas para la infancia-UNICEF- (2006). Convención sobre los derechos del niño. 20 de noviembre de 1989. Recuperado de https://www.un.org/es/events/childrenday/ pdf/derechos.pdf

Frigerio, G., y Diker, G. (2008). Infancia y derechos: Raíces de la sostenibilidad. Aportes para un porvenir. Santiago de Chile: Organización de Naciones Unidas para la Educación, Ciencia y la Cultura -UNESCO-.

García, F. (Ed.). (2000). La imagen del niño en la imagen. García, F., y Tripero, T. La representación del niño en los medios de comunicación, pp. 7-26

Gaviria, C. (director). (2010). Retratos en un mar de mentiras [película], Goggel, E. (productor).

González, G. (2002). Los niños de la guerra. Colombia: Aguilar.

González, G. (2019). Los niños de la guerra. Quince años después. Colombia: Aguilar.

Lamus (2001). Relatos de la violencia: impacto en la niñez y la juventud. Reflexión Política, 3(5), enero-jun, 2001. Universidad Autónoma de Bucaramanga, Colombia.

Larrossa, J. (2007). Las Imágenes de la Vida y la Vida de las Imágenes: tres notas sobre el cine y la educación de la mirada. Educação \& Realidade (32) (julio-diciembre). http://www.redalyc.org/ articulo.oa?id=317227046002

Larrosa, J. (2006). Niños atravesando el paisaje. Notas sobre cine e infancia. Dussel, I. y Gutiérrez, 
D. (comps.). Educar la mirada. Políticas y pedagogía de la imagen. Buenos Aires, Argentina: Manantial - Flacso - OSDE, pp. 113-114.

Larrosa, J. (2000). El enigma de la infancia o lo que va de lo imposible a lo verdadero. Estudios sobre el lenguaje, subjetividad, formación. http://educacion.uncuyo.edu.ar/upload/larrosa-el-enigma-de-la-infancia.pdf

Ley 418 (1997, 26 de diciembre). Por la cual se consagran unos instrumentos para la búsqueda de la convivencia, la eficacia de la justicia y se dictan otras disposiciones. https://www.mininterior.gov. co/sites/default/files/ley-418-de-1997.pdf

Ley 387 (1997, 18 de julio). Por la cual se adoptan medidas para la prevención del desplazamiento forzado; la atención, protección, consolidación y esta estabilización socioeconómica de los desplazados internos por la violencia en la República de Colombia. http://centrodedocumentacion. prosperidadsocial.gov.co/Documentos\%202019/Normativa/Leyes/1997/LEY-387-DE-1997.pdf

Ley 782 (2002, 23 de diciembre). Por medio de la cual se prorroga la vigencia de la Ley 418 de 1997, prorrogada y modificada por la Ley 548 de 1999 y se modifican algunas de sus disposiciones. https://www.funcionpublica.gov.co/eva/gestornormativo/norma.php?i=6677\#: :text=Disposiciones $\% 20$ para $\% 20$ facilitar\%20el\%20di\%C3\%A1logo,Corregido\%20por\%20el\%20art.\&text=Modifica\%20el\%20Art\%C3\%ADculo\%208\%20de\%201a\%20Ley\%20418\%20de\%201997

Ley 1448 (2011, 10 de junio). Por la cual se dictan medidas de atención, asistencia y reparación integral a las víctimas del conflicto armado interno y se dictan otras disposiciones. http://www. suin-juriscol.gov.co/viewDocument.asp?ruta=Leyes/1680697

Lozano y Morris (directores). (2011). Impunity [documental]. En Co-production Suiza-Francia-Colombia; Arte, Dolce Vita Films, Intermezzo Films S.A, Arte, SRG SSR Idée Suisse (productora).

Marzal, J., y Gómez, F. (2007). Interpretar un film. Reflexiones en torno a las metodologías de análisis del texto fílmico para la formulación de una propuesta de trabajo. Recuperado de https://www. academia.edu/2055466/Interpretar_un_film_Reflexiones_en_torno_a_las_metodolog\%C3\%ADas_de_an\%C3\%A1lisis_del_texto_f $\%$ C3\%ADlmico_para_la_formulaci $\%$ C3\%B3n_de_una propuesta_de_trabajo

Moreno, C. (director). (2011). Todos tus muertos [película]. Ramírez, D. F., Bustamante, D. y Fernández, N. (productores).

Ospina, M., Carmona, J., y Alvarado, S. (2014). Niños en contexto de conflicto armado: narrativas generativas de paz. Revista Imágenes de investigación. 13(1)-52-60. http://ceanj.cinde.org.co/ programa/Archivos/publicaciones/p1/1AN255.pdf

Pavez, I. (2012). Sociología de la infancia. Los niños y niñas como actores sociales. Recuperado de https://www.researchgate.net/publication/269970773_Sociologia_de_la_Infancia_las_ninas_y_ los_ninos_como_actores_sociales

Revista Semana (2014). Más de dos millones de niños víctimas. Recuperado de https://especiales. semana.com/especiales/conflicto-salud-mental/mas-de-2-millones-de-ninos-victimas.html

Rodríguez, P., y Manarelli, E. (2007). Historia de la infancia en América Latina. Colombia: Universidad Externado de Colombia. 
Rugeles, J. (director). (2015). Alias María [película]. Duán, F. (Productor).

Szir, S. (2006). Imágenes para la infancia. Entre el discurso pedagógico y la cultura del consumo en Argentina. La escuela y el periódico ilustrado. Caras y Caretas (1880-1910). Argentina: Universidad de Buenos Aires-. http://www.historicas.unam.mx/publicaciones/publicadigital/libros/ miradas/mirada006.pdf

Zapata, V. (1998). Cine, pedagogía e infancia. Revista Educación y Pedagogía, 10(22), 49-60. http:// aprendeenlinea.udea.edu.co/revistas/index.php/revistaeyp/article/view/24126

Zelis, O. (2012). La función del nombre en psicoanálisis: articulación entre las concepciones de J. Lacan y C. S. Peirce. IV Congreso Internacional de Investigación y Práctica Profesional en Psicología, XIX Jornadas de Investigación VIII Encuentro de Investigadores en Psicología del MERCOSUR. Buenos Aires: Facultad de Psicología - Universidad de Buenos Aires.

Zemelman, H. (2010). Sujeto y subjetividad: la problemática de las alternativas como construcción posible. Polis, Revista de la Universidad Bolivariana, 9(27), 355-366. https://scielo.conicyt.cl/ pdf/polis/v9n27/art16.pdf 


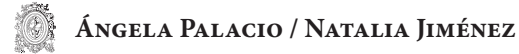

